\title{
The curious promise of educationalising technological unemployment: What can places of learning really do about the future of work?
}

\begin{abstract}
University education is full of promise. Indeed universities have the capacity to create and shape, through staff and students, all kinds of enthralling 'worlds' and 'new possibilities of life'. Yet students are encouraged increasingly to view universities as simply a means to an end, where neoliberal education delivers flexible skills to directly serve a certain type of capitalism. Additionally, the universal challenge of technological unemployment, alongside numerous other social issues, has become educationalised and portrayed in HE policy, as an issue to be solved by universities. The idea that more education can resolve the problem of technological unemployment is a political construction which has largely failed to deliver its promise. In this article we look at educationalisation in hand with technologisation and we draw on a Critical Discourse Analysis (CDA) of HE policies, to demonstrate the problems arising from taken for granted visions of neoliberal social development related to education, technology, and employment. To disrupt the tired visions of 'techno-fixes' and 'edu-fixes' we identify in these texts, we call for a radical re-imagining of HE policy. Instead of attributing responsibility for social change to abstract notions of education, market, and technology, a new shared vision is needed where more agency is explicitly attributed to the researchers, teachers, and students who are the genuine human future of work.
\end{abstract}

\section{Introduction}

The topic of employability has recently been the focus of policy reports and strategies, linked to arguments about value for money from university education (Skoulding, 2017). Higher Education (HE) is increasingly expected to directly 'enhance employability' (OECD, 2016). In this model, philosophy, self-discovery and critique of what surrounds us may be perceived as dispensible, in a rush to deliver graduates who meet the needs of the workplace. We would not argue with the importance of universities in supporting students towards future employment. However, taking a strategic and instrumental route alone through university, does not guarantee future work.

The idea that a university degree does not necessarily ensure a future of reliable and secure work is complicated by the emergent global challenge of technological unemployment. The notion of machines that replace human labor is not a new concern, but as of recently, it has become apparent that technological unemployment is a major challenge facing humanity. The problem is far from new: as Alexander Means emphasises in his recent article, "concerns over the displacement of human labor by machines are as old as capitalism itself" (Means, 2017: 23). Building on the Weberian theory of rationalisation, George Ritzer wrote of a continuation and acceleration of processes of efficiency and control which replace people with nonhuman technologies, using the example of fast food businesses (Ritzer, 1998: 52). Yet, despite the economies achieved, eventually a form of irrationality emerges from rationalisation (Ritzer, 1998: 54). The division of society from technology, and severing of human labour from our tools, is a major challenge for the future advancement of humanity.

While we read a rapidly increasing number of recent studies on technological unemployment, roughly situated between the opposed extremes of rejecting "the Luddite fallacy" which prevails mainstream economics (Tabarrok, 2003) and Frey and Osborne's (2013) prediction that emergent technologies might automate up to half of all jobs in the United States, it becomes clear that theories and solutions to technological unemployment are by and large based on three main pillars - analysis, extrapolation, and imagination - and at least two of these pillars reach beyond the realm of epistemic 'truth' and reach into the world of belief, mythology, fantasy, and utopia.

Since the beginning of Western civilisation, similar approaches can be found in studies of education. In the Republic Plato (380 BC/2006) imagines an ideal educational system for an ideal society; the German concept of Bildung "is the endless voyage of the individual towards him/her self as part of an ideal humanity" (Masschelein and Ricken, 2003: 140); John Dewey (1981) speculates that a certain type of education will bring about a certain type of (democratic) society; Ivan Illich's (1971) 
deschooling is a clear attempt at social change; the tradition of critical pedagogy freely admits its utopian (McLaren and Jandrić, 2014; Jandrić, 2017) and eschatologic (McLaren and Jandrić, 2017) character, and neoliberal education is clearly aimed at preservation and further development of a certain type of capitalism (Peters and Jandrić, 2018a). There is no such thing as 'pure' social science - belief, mythology, fantasy, and utopia are part and parcel of studies in education and work (McLaren and Jandrić, 2014 \& 2017). While the relationships between science and belief reach far beyond the scope of this article (see, for instance, the works of Sandra Harding (1991 and 2011) and the philosophical project of Science and Technology Studies), we do believe that the interplay between these important social forces presents an important opportunity for knowledge development.

One persistent myth, which constantly hovers between extrapolation and imagination, is the idea that more education will somehow make the world a better place. Therefore, shows Labaree, "modern Western societies have shown an increasing tendency to educationalise social problems" (2008: 447). Discussing Labaree's work, David Cuban explains this tendency as follows:

What 'educationalising' means is transferring societal structural problems to the institution of schooling so individual students and teachers then become first, an easy target to blame, and second, responsible for solving the problem. For example, national health problems of smoking tobacco and drinking alcohol in the prior century got translated into school courses for youth about the physical and cognitive damages done by both drugs. Too many road accidents? Driver training and completing a safe driver's course for high school graduation became a school-based solution to a national problem. And as you pointed out in your question, the harnessing of schools to an increasingly high-tech economy means that children and youth are engaged early and persistently in using electronic devices so that they can easily fit into a high-tech workplace. (Cuban and Jandrić, 2015: 434; see also Jandrić, 2017; Tyack and Cuban, 1995)

In the context of educational unemployment, educationalisation is an expectation that the future of work can be improved by more investment in education.

In this article we briefly outline the history of educationalisation of various social problems. We introduce the issue of technological unemployment, and map the main attempts at its educationalisation. From here though, due to an increasingly expanding technological view of society, we highlight a need to examine the educationalisation of social issues in hand with technologisation. Yet we take these arguments even further, to include much more than the obvious technologies that can lead directly to unemployment. If, as Ritzer (1998) asserted, processes of efficiency and control seek to replace people with nonhuman technologies, then we argue that a close analysis of higher education policy language concerning technology enhanced learning, student engagement, and employability, offers a productive route to expanding on the simple arguments of displacement of human labor by machines. As managerial agendas to increase efficiency in industry have flooded across into places of learning, written educational policies concerning the use of technology, student engagement and employability have reflected these priorities through nominalisation. This is when a verb that would normally describe the active processes of human labour, such as using technology, is altered in a policy statement to a noun describing 'the use of technology'. Furthermore, digital technologies have enabled certain political values to spread rapidly and become adopted globally. Coupled with new algorithmic possibilities to automate taught programmes, assessment and feedback, we now need to confront a cultural shift where we are all implicated in a use of language about education, technology and employment, that effectively edits out references to the real human labour that is required to address social issues (Hayes and Jandrić, 2014; Hayes and Bartholomew, 2015).

The patterns of texts we have used to illustrate this trend are drawn firstly, from a corpus of 2.5 million words of UK government policy and university strategy texts written between 1997-2012. These concern use of technology to support learning in Higher Education (HE), with these documents representing a large proportion of all of the UK HE policies written for this purpose during this period. They have been the focus of previous analysis which revealed "a tacit acceptance of a discourse based on the Marxist concept of "exchange value" (Marx, 1867, Hayes and Bartholomew, 2015: 114). This 
is reflected in repeated rational statements that (through nominalisation) assume that the use of technology will enhance learning, as a form of exchange value, or profit, but these fail to attribute the human labour of staff and students involved in such activities. Similar patterns can be observed in our second set of examples, drawn from a smaller corpus of student engagement policy documents, collected from UK university policies that are freely available on websites. These were analysed because the term of student engagement, like technology enhanced learning, appears to be attributed with a form of exchange value that provides benefits to universities, but conceals the human labour involved. Instead student engagement is treated as a commodity that might be 'embedded' and marketed back to students, rather than a time consuming human endeavour. Finally, a repetition of these linguistic patterns is demonstrated through a corpus of employability strategies, which many UK universities have recently produced to cover the period between 2015 - 2020.

We have included these because they imply that employability strategies, attributes frameworks, evaluation mechanisms and even module descriptors are addressing issues related to the future of work for students. These examples typically demonstrate a trend where students are now discussed in employability strategies in terms of 'attributes' they should acquire and bring to the workplace, but there are few acknowledgements of who (in terms of people) will perform the labour actions to ensure this happens. Therefore, using these texts to draw examples, we analyse some underlying expectations from education, in terms of use of technology, in addressing student engagement and to tackle employability issues. Rather than referencing the staff and students who provide the human labour for such expectations, there is a tendency to discuss students in terms of isolated 'attributes' that would ensure they were employable and to omit references to the employment roles of staff who teach skills to students or advise them on their careers. On the one hand, this approach of analysing policy texts could be critiqued for not actually proving anything. However, when repeated patterns are revealed, this provides data in the form of 'talking points' to discuss in the broader context of literature that this paper addresses. Finally, we assess opportunities and limitations of educationalising the problems of technological unemployment, and examine what universities can realistically do about the future of work.

\section{From educationalisation of social issues to educationalisation of the world}

It seems generally accepted that today's concept of educationalisation is based on the concept of pedagogisation (German: Pädagogisierung) developed by the Germany-based sociologist Janpeter Kob in late 1950s (Depaepe, Herman, Surmont, Van Gorp and Simon, 2008: 13). Depaepe et al. outline an important line of research around the concept of pedagogisation conducted in continental Europe by authors such as Helmut Schelsky, Frank Simon, and Jacques Ranciere. During the 1990s the concept reemerges in Anglo-Saxon literature (see, for instance, Cuban and Tyack, 1995; Labaree, 2008) under the name of educationalisation.

The simple mechanics of educationalisation creates profound theoretical and practical consequences in diverse aspects of society. Therefore, Lynda Stone describes educationalisation as "a complex, multidimensional institutional and rhetorical text formulation", which:

draws contingently on various exemplars of discursive evidence to set out aspects of school practices. Sources include philosophical and historical writings, government documents, political polemics, studies from the social sciences, cultural studies accounts, and media coverage. As the title suggests it is a present, a philosophical treatment, reminiscent of 'histories of the present' currently written by cultural historians of education but distinct. (...) it entails a strongly historicist position with origin in the concept of 'historicism'; it is also nominalist. (Stone, 2008: 61)

The historicist position is also prominent in Depaepe's view of educationalisation "as a key concept to understand fundamental processes in the history of Western education" (Depaepe, 2012 in Tröhler, 2016). Developing Depaepe's work, Tröhler suggests: 
By pointing at the fact that educationalising social problems continued to be a part of the educational culture even though schools have repeatedly proven that they are an ineffective mechanism for solving these problems, David F. Labaree (2008) pointed to a larger cultural context than education itself; it is precisely here that the term educationalisation of the world, a process starting in the long eighteenth century, gets a distinct meaning with regard to the educationalisation of social problems. (italics from the original)

In this way, educationalisation of the world is closely related to other important -isations such as medicalisation (Smeyers and Depaepe, 2008), modernisation, secularisation, etc.

One of the most prominent -isations of today is technologisation (Illich, 1971; see also Jandrić, 2014), which, according to Smedts, "is a continuation of educationalisation" (2008: 114). Educationalisation is much more than mere transfer of social problems to schools, and "technologisation in its turn is not just about the introduction of devices at home; technology is not a mere artefact or tool. More than this, it pertains to an increasingly expanding technological view of society." (ibid: 113). In a recent interview, Larry Cuban arrives to a similar conclusion:

the harnessing of schools to an increasingly high-tech economy means that children and youth are engaged early and persistently in using electronic devices so that they can easily fit into a high-tech workplace. What you call 'technologising' to me becomes just another instance of policy elites 'educationalising' a national economic problem into school reforms focusing on teacher and student use of devices, implying that such access and use of devices in schools across the country will somehow improve national economic growth and productivity. (Cuban and Jandrić, 2015: 434; see also Jandrić, 2017)

Lynn Fendler analyses the role of educationalisation as an important mechanism in Deleuze's (1992) 'society of control', and identifies the resulting "current educationalising trend of investigating the world in terms of problems to be solved" (2008: 55). Following Cruikshank (1999) Fendler shows: "From this point of view, the appeal of educationalising trends becomes apparent. Educationalising is desirable because it empowers people and solves problems" (ibid: 57). Educationalisation thus becomes a political issue, which is dialectically intertwined with "the effects of educationalising technologies," which "are shaped by the historically specific characteristics of those technologies" (Fendler, 2008: 58).

In order to explore the promise of educationalising technological unemployment, we need to explore educationalisation in hand with technologisation using a historicist position of educationalisation and technologisation of the world, with an accent to their political and ideological underpinnings.

\section{Educationalising technological unemployment: A Critical Discourse Analysis}

The trend we have discussed, with regard to educationalising social problems, appears to extend into a pattern of subsequently technologising a range of educational issues. So in this section we first discuss examples from policy where technology is attributed with the power to simply address all manner of social issues, and then take a close look at statements from some recently published employability strategies. Through this approach we can demonstrate connections over time, and across different forms of policy, where a persistent type of discourse, or language in action, effectively omits references to human agency from the activities of learning, teaching and employment. A rational logic communicated in the largest collection of policy texts that we examined, tends to suggest, whether welfare or education is the 'issue', we might seek to use technology as the 'response', or 'technofix' (Clegg, Hudson \& Steel, 2003: 49). Other authors have discussed a history of 'fix-it' policies in education (Selwyn, Gorard, \& Williams, 2001) which have contributed to a narrow and dominant language about educational technology, as always resulting in an 'exchange value' for learning (Hayes \& Jandrić, 2014; Hayes \& Bartholomew, 2015: 115). 
The first set of examples are drawn from a large corpus of UK policy texts concerning use of technology to support learning in Higher Education (HE). A corpus is a collection of naturally occurring language which has been compiled for analysis. Corpus linguistics (Baker, 2006) provides a principled way to search such texts to examine constructions of language. Whilst these initial quantitative findings do not prove much, beyond pointing to repetition of certain patterns, a more qualitative approach through Critical Discourse Analysis (CDA), can then be used to closely examine grammatical structures in relation to critical theory, to provide interesting talking points. In a first step, software called Wordsmith enabled searching and identifying quantitative patterns in the corpus. Wordsmith provides insights through keywords (Scott, 1997). Keywords are words that are statistically significant when the language under scrutiny is measured against a comparison corpus, in this case, the British National Corpus.

\begin{tabular}{|l|l|}
\hline Keyword & Number of instances \\
\hline Learning & 19260 \\
\hline Use & 8131 \\
\hline Technology & 6079 \\
\hline
\end{tabular}

Table 1: example keywords their frequency in the corpus.

Table 1 shows some of the keywords that were highlighted and the number of times they appeared in the corpus. To see how these keywords are frequently positioned, Figure 1 below shows some example concordance lines of policy text.

\begin{tabular}{|ll|}
5659 & the use of technology can increase accessibility and flexibility of learning \\
5660 & the use of technology to create digital archives to improve practice \\
5661 & the use of technology to enhance front line productivity and management \\
5665 & the agenda to enhance learning and teaching through the use of technology \\
5677 & produce resources and advice on the use of technology to enhance assessment \\
5680 & enhancing their skills and confidence in the use of technology enhanced learning \\
5681 & to enhance the use of technology in learning and teaching and to facilitate a more \\
5682 & to share information and drive the use of technology to enhance learning \\
5683 & to improve the student learning experience through the use of technology \\
5684 & the use of technology to achieve novel and effective learning experiences \\
5686 & support for use of technology to enhance the learning and teaching experience \\
\hline
\end{tabular}

Figure 1: Concordance lines of policy text showing patterns of keywords in Wordsmith.

A concordance illustrates how words and phrases are ordered alongside each other in their actual context of use. There is a repeated emphasis in Figure 1 on ways in which 'the use of technology' is expected to 'increase', 'enhance' or 'improve' accessibility, flexibility, productivity and management. Though there appears to be a pattern of this assumption, a closer look through CDA, is a more qualitative way to examine these grammatical structures and to critically reflect on what sorts of values seem to be implicit within them. CDA is one way to expose the choices people make in policy language (Fairclough, 2007), whether these are conscious decisions or not. Therefore using a form of CDA known as transitivity analysis (Halliday, 1994) it becomes possible to label grammatical patterns. In transitivity analysis, verbs reveal different types of active processes, and nouns tell us who or what is actually 'doing' these. So in some further concordance lines below, the noun that undertakes all of the processes (shown in italics: to create, to promote, to overcome etc) is 'the use of technology' (shown in bold). This is not a lecturer, student, administrator or manager. It is a textual construction that represents no human being, but the items underlined quite clearly include key social issues: 
'the use of technology to create, sustain and develop reflective learning communities'

5523 'the use of technology to overcome problems, circumvent disability, or finding alternatives'

5547 'the use of technology in meeting the needs of a diverse student body'

There is not scope within this article to explain in detail the specific linguistic forms of analysis that might be undertaken in CDA. For more on applying corpus-based CDA to educational technology policy discourse, using transitivity analysis, please see (Hayes \& Bartholomew, 2014; Hayes, 2016).

\section{Examining the role of nominalisation}

In linguistics, changing an active process of using technology into 'the use of technology' is called a 'nominalisation' and it refers to a verb being changed into a noun. When we write in this way there are implications which may not be apparent to a reader at first, as shown in corpus line 5547:

\section{7 'the use of technology in meeting the needs of a diverse student body'}

The statement in 5547 could be rewritten as:

'Sarah is using technology to meet the needs of a diverse student body'

In the second, alternative way of stating what is happening, 'Sarah' would then become the noun. Sarah would be the named person, or human being, undertaking the material process, expressed by the verb in italics: to meet. The writer of corpus line 5547 has replaced active human labour (where Sarah was using technology) with a static construction (the use of technology) that now acts on Sarah's behalf. This is a common pattern identified in the large quantity of analysed educational technology policy documents. Human agency was repeatedly delegated to objects (expressed as nouns) rather than to people. We could ask: So what? Many policy documents are simply written in this way as merely a form of shorthand. Yet, moving around to examine other sections of the corpus, there is a sustained repetition of these linguistic structures, both in teaching contexts and beyond, as illustrated here with some commentary on the potential effects of persistently writing in this way:

\section{Technology is introducing far-reaching changes into learners' lifestyles}

5485 'the use of technology to enhance assessment and the provision of feedback by identifying and promoting evidence-based practice'

In corpus line 2704, 'technology', not lecturers is attributed with changing learner's lives. In 5485, 'the use of technology' is credited with being able to enhance assessment and the provision of feedback. It is expected to do this by: identifying and promoting evidence-based practice'. So how exactly does a statement: 'the use of technology', go about identifying and promoting human practice? Indeed whose evidence-based practice? How is 'evidence-based practice' defined? Given that technology does not speak, think or create, without the aid of human programmers (at least not yet...), in HE policy we attribute it with considerable powers of discrimination, to determine things on our behalf, that at the same time detract from human labour. In the following examples, similar patterns can be observed:

5457 'the use of technology to support and enhance the business and management functions of educational institutions. Employed effectively, it can lead to greater efficiency'

In line 5457, 'the use of technology' is also attributed with power to enhance functions that go well beyond teaching alone. It is said to support and enhance the 'business and management functions' of the university, leading to greater efficiency. Even if this is true, there is still no mention of the human 
beings whose labour (not forgetting their related anxieties and emotions) that would enable such a deployment of technology. We are left to imagine what constitutes effective employment of the use of technology, what is deemed to be 'greater efficiency' and so would surely be justified in asking: 'Greater than what?'.

Verbs mentioned so far, such as 'support' and 'enhance' are discussed in transitivity analysis as 'material' processes. Yet many of the examples we found were also enacting forms of speech on behalf of people, which might be identified also as 'verbal' processes:

7008 'the strategy outlined a number of key aims and objectives, the first of which echoes the policy context for transformation in emphasising the use of technology to transform higher education

In 7008 it is 'the strategy' that has (verbally, or otherwise) outlined the key aims and objectives, but later through the verbal process: in emphasising it is clear that 'the strategy', and not a person, places this emphasis on: 'the use of technology' which is expected to transform 'higher education'.

\section{Educationalization and technologization of social issues}

Now that these patterns of linguistic data from HE policy have been highlighted through the example of technology enhanced learning, observations can be made regarding educationalisation of all sorts of social issues. A major concern for universities is to retain the students they recruit, given the many psychological issues that now assail the student body, such as depression, loneliness, different forms of addiction or indifference. In the example below, we see that 'recruitment and retention' are both technologized and educationalised:

\section{8 'Evidence suggests that the use of technology can improve recruitment and retention}

In 7238 we see a similar patter where it is 'evidence' (not humans) that suggests that 'the use of technology' can actually improve recruitment and retention. If it were this simple though, would we then need the growing range of student support departments now established for this work in universities, on top of the long hours that lecturers spend in pastoral support and personal tutoring consultations with their students?

\section{5 'Capital-funded projects are helping to widen participation in education'}

In 6965, once more, the nouns that are acknowledged for addressing a range of educational issues extend well beyond statements about technology alone, to ones that attribute human labour to, for example, 'capital-funded projects'. If only our funded projects did run themselves in this way, contributing to social justice as they go! In practice however, those of us working in the areas of widening participation know what a struggle it is to foster inclusivity, in a society where many other factors prevent social mobility.

6966 the use of technology to encourage non-traditional groups of students, engage employers and support lifelong learning.

In critical response to 6966, we can question the quick fix that 'the use of technology' is expected to deliver regarding social issues such as 'non-traditional groups of students' and support of lifelong learning. It seems we no longer require humans to encourage these groups of participants or indeed to engage employers. Yet, when many universities are not actively engaging employers, the suggestion that a use of technology alone can do this, seems irrational and naïve.

\section{Student engagement strategies}

The next few examples are drawn from a corpus of university student engagement strategies $(62,000$ 
words) and from a corpus of employability strategies $(103,000)$. Whilst these collections of documents are not as large as the technology enhanced learning corpus, there are similar patterns that persistently attribute human labour to non-human entities. The examples below provide illustrative content to notice where value appears to be being placed. Ironically, given the topic, an institutional, rather than a student or staff focus, seems to prevail.

29 Effective student engagement offers a range of benefits to the University

67 It is important that the ethos of student engagement reaches every corner of the University

In the next few examples there is a focus on 'embedding' various forms of human activities

64 The College recognises the importance and value of embedding student engagement into operating practices and systems within the institution

Irrationality emerges in (64) causing us to ask exactly how one embeds a form of human engagement, that we expect students to enact, into institutional operating practices and systems?

80 This strategy outlines the aim to continue to embed a culture and ethos of student engagement throughout the University

In (80) this strategy is the actor who outlines the aim to continue to embed a culture and ethos of student engagement throughout the University. The word 'ethos' suggests that student engagement has a particular character, but given human individual differences and motivation, this is a curious way of packaging human attributes into forms that are easily referred to within policy discourse.

81 Outcome measures are measures of the wider impact of student engagement to identify how it is making a difference

In (81) it is student engagement, rather than human beings, that is making a difference, in terms of impact, through outcome measures:

$84 \quad$ Packaging, marketing and communicating student engagement to applicants, current students and staff.

It seems that in (84) student engagement can also be packaged, marketed and communicated to applicants, current students and staff. Once more, how exactly does a form of human engagement (that we expect students to enact) become 'packaged' and then marketed and communicated back to the students who engage?

According to neoliberalist ideology, knowledge is a commodity and HE is a market where knowledge and skills are traded (Zepke, 2014: 702). Universities offer marketable knowledge and skills, as well as supplying marketable services (Codd, 2005), so perhaps the idea that engagement can be packaged, marketed and communicated is not so strange after all. Yet, in relation to critical theory this 'trafficking in human attributes' (Kopytoff, 1986: 85) is problematic in the context of learning (see also Hayes \& Jandrić, 2014), but as in the next set of examples, also in the context of work and employment.

\section{Employability strategies}

Since 2012 there has been a surge in the number of policy documents produced by universities to address the topic of 'employability'. In the examples below we highlight how the patterns we identified in the technology enhanced learning corpus and student engagement corpus can be noticed in the 
employability strategies of universities. The response to the threat of technological employment is not explicitly addressed but what is implied is that people can be moulded and shaped to provide what employers require. There are few acknowledgements of who (in terms of people) perform the labour actions to ensure this happens. Instead, as shown below, the actions mentioned are enacted by frameworks, agendas, evaluation mechanisms and even module descriptors! These statements are from strategies that cover 2015 - 2020. They also typically demonstrate a trend where students are now discussed in terms of the required 'attributes' they should acquire and bring to the workplace:

492 'the Awards will provide further opportunities for students to reflect on attribute development'

$510 \quad$ A set of core attributes and capabilities are identified by graduate recruiters as indicators of their needs and as hallmarks of 'graduateness'.

764 Define and articulate five graduate attributes which enable our graduates to thrive in their personal and professional lives as highly employable, socially responsible and globally engaged citizens

In these examples from Employability Strategies written between 2014-17 this pattern is often repeated, with the actions of humans attributed to 'The Graduate Attributes Framework' or the University or the Employability and Enterprise Strategy:

39 The Graduate Attributes Framework will enable all departments to review their provision and assess how the attributes are delivered within programmes of study

Furthermore, the statement above seems to imply that such attributes are simply delivered within programmes of study. This expectation that a curriculum will deliver these skills continues:

92 The University has identified a number of key areas of provision that directly address graduate attributes and employability

242 The equipping of all graduates with these attributes is integrated as an objective of all aspects of the curriculum

In these examples from 2016, the curriculum or areas of provision (not humans) are given the responsibility to equip graduates with the required attributes.

In the next set of examples below this pattern continues, but with an emphasis on who will ensure that the market is served by coherent brands, consistency of provision and evaluation of effectiveness:

163 Key strategic priorities of the Employability and Enterprise Strategy for 2014-2017 are to ensure that the skills, qualities and graduate attributes aligned to employability and enterprise are embedded effectively within the curriculum

174 Coordination of marketing across these functions is required to ensure the presentation of a coherent brand to the market.

207 employability provision should be structurally unavoidable to tackle the issue of student nonengagement and to ensure consistency of provision.

141 the University's governance structure for education should ensure oversight and on-going evaluation of the effectiveness and outcomes of the delivery of the strategic framework for employability 149 Evaluate feedback mechanisms and module descriptors to ensure that employability skills embedded in the curriculum are highlighted and clarified to students.

150 Strategic planning of capital 14-19 investment to ensure capital investment in specialist resources is maximised

As this application of language enacts the so-called 'techno-fix' and 'edu-fix' on our behalf in a range of contexts, the policy documents themselves in which these statements sit, are materially implicated in educationalisation and technologisation within capitalism. No one can be held accountable, the policy 
statements tell it the way it is, but who wrote these policies? In very few of the policies examined were there any named authors, let alone any publicised mechanism by which the policy might be updated or changed (Bartholomew \& Hayes, 2015: 28).

\section{The higher education 'law of gravitation' and its ideology}

In order to meet expectations of accreditation agencies and funding bodies, higher education institutions are required to maintain a growing number of policy documents. The task of writing these documents often ends up with lower-ranking academics and administrators who, looking at documents from other institutions, emulate the tone and language of available 'successful' examples. Upon writing, such policy documents get approved at various levels from departmental boards to university senates. Traveling through many different levels of HE management, strategies and policies get rewritten, rephrased, reiterated, and approved without much consideration for their actual content - for as long as they tick boxes required by relevant (usually external) bodies, these documents are rarely discussed and / or challenged. In Risk Society: Towards a New Modernity, Ulrich Beck links this dispersion of responsibility with the structure of labor.

Corresponding to the highly differentiated division of labor, there is a general complicity, and the complicity is matched by a general lack of responsibility. Everyone is cause and effect, and thus non-cause. The causes dribble away into a general amalgam of agents and conditions, reactions and counter-reactions, which brings social certainty and popularity to the concept of system.

This reveals in exemplary fashion the ethical significance of the system concept: one can do something and continue doing it without having to take personal responsibility for it. It is as if one were acting while being personally absent. One acts physically, without acting morally or politically. The generalized other - the system - acts within and through oneself: this is the slave morality of civilization, in which people act personally and socially as if they were subject to a natural fate, the 'law of gravitation' of the system. (Beck, 1992: 33, italics from the original)

With the increasing neoliberalization of the HE sector, the higher education 'law of gravitation' disperses responsibility of academics for actual content of policy documents. This is reflected in policy discourse which transfers academics' individual and collective human agency to faceless 'techno-fixes' and 'edu-fixes', where various social effects of education, including but far from limited to employability, are transferred from people to abstract 'actors' such as policy documents, marketplaces, technologies, and education at large. Such transfer of responsibility is based on two dialectically interconnected utopian ideas: (1) If we provide enough education, work markets will take care of themselves, and (2) If we provide enough technology, work markets will take care of themselves.

Speaking of education, Peters and Jandrić (2018a and 2018b; see also Peters, 2017) link educationalization of technological unemployment to the concept of human capital and its main protagonist the homo economicus. They juxtapose the concept of homo economicus (as the main protagonist of the age of industrial capitalism) with the concept of homo collaborans (as the main protagonist of the age of digital reason) as follows:

The assumption of individuality is counter posed by collective intelligence (Lévy, 2015; Peters, 2015a; Peters, Jandrić, Irwin, Locke, Devine, Heraud, Gibbons, Besley, White, Forster, Jackson, Grierson, Mika, Stewart, Tesar, Brighouse, Arndt, Lazariou, Mihaila, Bernade, Legg, Ozolins, and Roberts, 2016), that can take different forms from collective awareness and consciousness, to collective intelligence, responsibility and action. The assumption of rationality is contradicted in a networked environment as the ontological basis is contained in the relations between entities rather than any one self-sufficient entity that is rationally aware and transparent to itself. The network is a very different kind of epistemic set of relations rather than the individual knowing 
agent. Finally, the assumption of self-interest again tends to be offset or decentred by forms of collective responsibility. In a connected world there are no clear boundaries in either the physical or social worlds. (Peters and Jandrić, 2018a: 343)

Based on this juxtaposition, they show that "educational solutions based on the concepts of human capital and homo economicus are unable to resolve the problem of technological unemployment", and conclude "that contemporary education requires a non-suprecessionist approach based on the figure of homo collaborans which fundamentally rethinks the concepts of work, education, and research" (Peters and Jandrić, forthcoming, 2018c).

Speaking of technology, Hayes and Jandrić use Critical Discourse Analysis to explore the position of people in higher education policy discourse and notice an interesting phenomenon: "in policy about human labour with technology for learning, the references to humanity have by and large disappeared" (Hayes and Jandrić, 2014: 195). Analysing ideological underpinnings of this trend using an array of neo-Marxist approaches including but not limited to postcolonialism and critical pedagogy, they conclude that "the omission of humans from higher education policy discourse is just one more attempt of global neoliberal capitalism to find its way into a very important part of our commons education of future generations. (ibid: 208).

Analysing utopian ideas about relationships between education, technology, and employability we arrive to two conclusions. First, the 'law of gravitation' which claims that more education and more technology will somehow resolve the problem of educational unemployment is at least unsupported by evidence, if not plainly wrong. Second, utopian 'techno-fixes' and 'edu-fixes' have strong underpinnings in ideology of neoliberalism. In policy documents, the lack of agency which Beck identified a decade ago has developed into a more advanced form: omission of humans, and transfer of agency to abstract concepts such as policy documents and education at large. This trend is not a naïve example of utopian or animistic thinking, because it strongly supports a certain kind of social development - it is through policy documents that places of learning shape a significant part of their future. In this way, educationalisation and technologisation of technological unemployment become battlefields between opposed worldviews and ideologies, and sites for emancipatory resistance.

\section{What can places of learning really do about the future of work?}

In the year 2017, the described processes are quite advanced. Policy documents seem to write themselves using same templates and linguistic formulations, and animistic nominalisation of human agency to abstract concepts is common and ubiquitous. Thus, the higher education 'law of gravitation' arrives closer and closer to a self-fulfilling prophecy. While the discursive battle can be fought at many fronts, such as streets, classrooms, and university boards, emancipatory struggle needs to start from ideological resistance to the utopian views that education can resolve the problem of technological unemployment. In the context of education, Ivana Milojević sums up three crucial elements of such resistance:

First is the realization that what is considered utopian and what are considered real futures probabilities or possibilities are, in fact, political constructions. Second, it is thus important to see that 'taken for granted' futures visions are also utopian. Even the 'realistic' discourse of the 'imminent' future is constituted by desire and imagination, about what is hoped for. And third, it is important to bring in and discuss the alternatives to hegemonic futures. By exploring alternative visions of what our societies and education can become, we can show that possible alternatives can exist and that 'these alternatives can be as 'real' as our reality' (Halbert, 1994: 29). (Milojević, 2006: 40)

The idea that education can resolve the problem of technological unemployment is a political construction which has by and large failed to deliver its promise. Instead of animistic attribution of agency to abstract concepts such as 'use of technology', 'strategy', 'framework', or even education at large, we should therefore give more agency to actual researchers, teachers, and students. Policy 
documents implicitly and explicitly draw from taken for granted visions of neoliberal social development and the associated understandings of concepts such as education, technology, and employment. In order to counter taken for granted visions, we need to reinvent these concepts, and the associated policy language, to include opportunity for radically different, non-supercessionist futures. Finally, we need to create new visions, and imagine different social orders, where concepts such as education, technology, and employment may acquire radically different meanings.

The process of opening our minds and discourses to non-supercessionist futures will be long and tedious. Learning from historicist understanding of educationalization, we can rest assured that these developments will never provide a one-size-fits-all answer to the question: What can places of learning really do about the future of work? However, as it becomes increasingly clear that educationalization is a site of political struggle, we need to open new imaginary, physical, and discursive spaces for resistance and reimagination - and the first step in that direction is to return agency from abstract notions of education, market, and technology, to people, their present needs, and future wishes.

\section{References}

Baker, P. (2006). Using Corpora in Discourse Analysis. London: Continuum.

Bartholomew, P. \& Hayes, S. (2015). An Introduction to Technology-enhanced Learning Policy' In Branch, J., Bartholomew, P. \& Nygaard, C. (Eds) Technology Enhanced Learning in Higher Education. London: Libri Publishing, $17-29$.

Beck, U. (1992). Risk Society: Towards a New Modernity. London: SAGE.

Brynjolfsson, E. \& McAfee, A. (2011). Race against the machine: How the digital revolution is accelerating innovation, driving productivity, and irreversibly transforming employment and the economy. Lexington, MA: Digital Frontier Press.

Brynjolfsson, E. \& McAfee, A. (2016). The Second Machine Age: Work, Progress, and Prosperity in a Time of Brilliant Technologies. New York: W. W. Norton \& Company.

Clegg, S.; Hudson, A.; and Steel, J. (2003). The Emperor's New Clothes: Globalisation and E- Learning in Higher Education. British Journal of Sociology of Education, 24(1), 39-53.

Codd, J. (2005). Education policy and the challenges of globalisation: commercialisation or citizenship? In J. Codd and K. Sullivan (Eds) Education Policy Directions in Aotearoa New Zealand, Melbourne: Thomson Dunmore Press, 3-17.

Cruikshank, B. (1999). The will to empower: Democratic citizens and other subjects. Ithaca: Cornell University Press.

Cuban, L. \& Jandrić, P. (2015). The dubious promise of educational technologies: historical patterns and future challenges. E-Learning and Digital Media, 12(3-4), 425-439.

Deleuze, G. (1992). Postscript on the societies of control. October, 59, 3-7.

Depaepe, M.; Herman, F.; Surmont, M.; Van Gorp, A. \& Simon, F. (2008). About Pedagogization: From the Perspective of the History of Education. In P. Smeyers and M. Depaepe (Eds.), Educational Research: the Educationalization of Social Problems. Springer Science+Business Media, 1330.

Dewey, J. (1981). Creative Democracy: The Task before Us. In . J. A. Boydston (Ed.), The Later Works of John Dewey, 1925- 1953. Vol. 14: Essays. Carbondale, IL: Southern Illinois University Press, 224-230.

Fairclough, N. (2007). Global Capitalism and Change in Higher Education: Dialectics of Language and Practice, Technology, Ideology. In proceedings from $40^{\text {th }}$ British Association for Applied Linguistics BAAL conference: Edinburgh. 6 - 8 September, 2007.

Frey, C. B. \& Osborne, M. A. (2013). The future of employment: How susceptible are jobs to computerization?

http://www.oxfordmartin.ox.ac.uk/downloads/academic/The_Future_of_Employment.pdf.

Halliday, M.A.K. 1994. An introduction to functional grammar. London: Arnold.

Harding, S. (1991). Whose Science? Whose Knowledge? Thinking from Women's Lives. Ithaca (NY): Cornell University Press. 
Harding, S. (Ed.) (2011). The Postcolonial Science and Technology Studies Reader. Durham and London: Duke University Press.

Hayes, S. \& Bartholomew, P. (2015). Where's the Humanity? Challenging the Policy Discourse of Technology Enhanced Learning. In Branch, J., Bartholomew, P. \& Nygaard, C. (Eds) Technology Enhanced Learning in Higher Education. London: Libri Publishing, 113 - 133.

Hayes, S. \& Jandrić, P. (2014). Who is Really in Charge of Contemporary Education? People and technologies in, against and beyond the neoliberal university. Open Review of Educational Research, 1(1), 193-210.

Hayes, S. (2016). Learning from a deceptively spacious policy discourse. In Ryberg, T., Sinclair, C., Bayne, S., \& De Laat, M. Research, Boundaries, and Policy in Networked Learning (pp. 2340). Springer International Publishing.

Illich, I. (1971). Deschooling Society. London: Marion Boyars.

Jandrić, P. (2014). Deschooling Virtuality. Open Review of Educational Research, 1(1), 84-98.

Jandrić, P. (2017). Learning in the Age of Digital Reason. Rotterdam: Sense.

Kopytoff, I. (1986) 'The cultural biography of things: commoditisation as process'. The Social Life of

Labaree, D. F. (2008). The winning ways of a losing strategy: Educationalizing social problems in the United States. Educational Theory, 58(4): 447-460.

Marx, K. (1867).Capitalism and the modern labour process. Capital, volume 1. In R. C. Scharff \& V. Dusek (Eds). (2003). Philosophy of technology: The technological condition: An anthology. Oxford, UK: Blackwell.

Masschelein, J. \& Ricken, N. (2003). Do We (Still) Need the Concept of Bildung? Educational Philosophy and Theory, 35(2), 139-154.

McLaren, P. \& Jandrić, P. (2014). Critical revolutionary pedagogy is made by walking - in a world where many worlds coexist. Policy Futures in Education, 12(6), 805-831.

McLaren, P. \& Jandrić, P. (2017). From Liberation to Salvation: Revolutionary critical pedagogy meets liberation theology. Policy Futures in Education, 15(5), 620-652.

Means, A. (2017). Education for a post-work future: automation, precarity, and stagnation. Knowledge Cultures, 5(1): 21-40.

Milojević, I. (2006). Hegemonic and Marginalised Educational Utopias in the Contemporary Western World. In M. A. Peters \& J. Freeman-Moir (Eds.), Edutopias: New Utopian Thinking in Education. Rotterdam: Sense, 21-44.

Organisation for Economic Co-operation and Development (OECD) International Labour Organisation (ILO); World Bank (IBRD); International Monetary Fund (IMF). (2016). Enhancing employability: report prepared for the G20 Employment Working Group. https://www.oecd.org/g20/topics/employment-and-social-policy/Enhancing-EmployabilityG20-Report-2016.pdf

Peters, M. A. \& Jandrić, P. (2018a). The Digital University: A Dialogue and Manifesto. New York: Peter Lang.

Peters, M. A. \& Jandrić, P. (2018b). Neoliberalism and the university. In D. Cahill, M. Koenings \& M. Cooper (Eds.), SAGE Handbook of Neoliberalism. London: Sage, 553-564.

Peters, M. A. \& Jandrić, P. (forthcoming, 2018c). Education and technological unemployment in the Fourth Industrial Revolution. In S. Crump; A. Drew, \& G. Redding (Eds.), Oxford Handbook of Comparative Higher Education Systems and University Management. Oxford: Oxford University Press.

Peters, M. A. (2017). Technological unemployment: Educating for the fourth industrial revolution. Educational Philosophy and Theory, 49(1): 1-6.

Plato (380 BC/2006). The Republic. Trans. R. E. Allen. New Haven: Yale University Press. Ritzer, G. (1998). The Weberian Theory of Rationalization and the McDonaldization of Contemporary Society. Illuminating Social Life: Classical and Contemporary Theory Revisited, 37-61. 
Schwab, K. (2016). The fourth industrial revolution, Davos 2016. Retrieved from http://www.weforum.org/agenda/2016/01/the-fourth-industrial-revolution-what-it-means-andhow-to-respond.

Scott, M. (1997). PC Analysis of Key Words - and Key Key Words. System, 25(2), 233-245.

Selwyn, N.; Gorard, S. \& Williams, S. (2001). The role of the 'technical fix' in UK lifelong education policy. International Journal of Lifelong Education, 20(4), 255-271.

Skoulding, L. (2017). Report: The UK universities offering best value for money. Student News, 5 May 2017. http://www.savethestudent.org/news/revealed-which-universities-offer-students-bestvalue-for-money.html

Smedts, G. (2008). Parenting and the Art of Being a Parent. In P. Smeyers and M. Depaepe (Eds.), Educational Research: the Educationalization of Social Problems. Springer Science+Business Media, 109-124.

Smeyers, P., \& Depaepe, M. (Eds.). (2008). Educational research: The educationalization ofsocial problems. Dordrecht: Springer.

Stone, L. (2008). Educationalization in a USA Present: A Historicist Rendering. In P. Smeyers and M. Depaepe (Eds.), Educational Research: the Educationalization of Social Problems. Springer Science+Business Media, 61-78.

Tabarrok, A. (2003). Productivity and unemployment. http://marginalrevolution.com/marginalrevolution/2003/12/productivity_an.html. Things: Commodities in cultural perspective, 68: 70-73.

Tröhler, D. (2016). Educationalization of Social Problems and the Educationalization of the Modern World. In M. A. Peters (Ed.), Encyclopedia of Educational Philosophy and Theory. Singapore: Springer Science+Business Media.

Tyack, D. \& Cuban, L. (1995). Tinkering Toward Utopia: A Century of Public School Reform. Cambridge (MA) and London (UK): Harvard University Press.

Zepke, N. (2014). 'Student engagement research in Higher Education: questioning an academic orthodoxy'. Teaching in Higher Education 19, no. 6: 697-708. 